ANDRIOLO, J.L.; LUZ, G.L.; WITTER, M.H.; GODOI, R.S.; BARROS, G.T.; BORTOLOTTO, O.C. Growth and yield of lettuce plants under salinity. Horticultura Brasileira, Brasília, v.23, n.4, p.931-934, out-dez 2005.

\title{
Growth and yield of lettuce plants under salinity
}

\author{
Jerônimo L. Andriolo; Gean L. da Luz ${ }^{2}$; Maiquel H. Witter ${ }^{3}$; Rodrigo dos S. Godoi ${ }^{1}$; Gisele T. Barros ${ }^{1}$; \\ Orcial C. Bortolotto ${ }^{4}$ \\ ${ }^{1}$ UFSM, CCR, Depto. Fitotecnia, 97105-900 Santa Maria-RS; E-mail: andriolo@smail.ufsm.br; ${ }^{2}$ Acadêmico do curso de agronomia, \\ UFSM; ${ }^{3}$ Bolsista PIBIC-CNPq; ${ }^{4}$ Bolsista FAPERGS
}

\begin{abstract}
Lettuce plants, cv. Vera, were grown under five salinity levels in a hydroponical experimental set-up using a $0.15 \mathrm{~m}$ deep sand growing bed. A standard nutrient solution was used, with the following composition, in mmol L-1: $16.9 \mathrm{NO}_{3}^{-} ; 2.0 \mathrm{H}_{2} \mathrm{PO}_{4}^{-} ; 1.0 \mathrm{SO}_{4}^{-} 4.0 \mathrm{Ca}++$; $10.9 \mathrm{~K}+$ e $1.0 \mathrm{Mg}++$, and, in $\mathrm{mg} \mathrm{L}^{-1}, 0.42 \mathrm{Mn} ; 0.26 \mathrm{Zn} ; 0,05 \mathrm{Cu}$; $0,50 \mathrm{~B} ; 0,04 \mathrm{Mo}$, and 4.82 chelated Fe. The five salinity levels compared as treatments were obtained by varying the concentration of the standard nutrient solution, reaching average electrical conductivities (EC) of $0.80 ; 1.93 ; 2.81 ; 3.73$ and $4.72 \mathrm{dS} \mathrm{m}^{-1}$, for T1, $\mathrm{T} 2, \mathrm{~T} 3, \mathrm{~T} 4$ and $\mathrm{T} 5$, respectively. The nutrient solution at each salinity level was supplied from a reservoir by means of a flooded-type electrical pump, for 15 minutes, at intervals of 90 minutes during the day and 420 minutes during the night. A completely randomised experimental design was used with four replications and 20 plants per plot. Four plants of each plot were harvested at 32 days after planting, to determine shoot and root dry mass, shoot fresh weight, leaf area and number of leaves per plant. Number of leaves was 18 per plant and was not affected by treatments. Dry mass of leaves increased $24,4 \%$ from $\mathrm{T} 1$ to T3. No relationships were found on data from stem and root dry mass. A positive effect of EC was recorded on shoot fresh mass, which increased $28.5 \%$ from $\mathrm{T} 1$ to $\mathrm{T} 2$, and decreased $16.5 \%$ from T2 to T5. Maximum LAI estimated value was $4.3 \mathrm{~m}^{2} \mathrm{~m}^{-2}$ for an EC of $2.6 \mathrm{dS} \mathrm{m}^{-1}$. Salinity levels above 2.0 and $2.6 \mathrm{dS} \mathrm{m}^{-1}$ reduce fresh yield and plant growth, respectively.
\end{abstract}

Keywords: Lactuca sativa, fertigation, hydroponics, salinity.

\section{RESUMO}

Crescimento e produtividade da alface em condições salinas

Plantas de alface, cv. Vera, foram cultivadas em cinco níveis de salinidade em um dispositivo experimental composto por uma camada de areia de $0,15 \mathrm{~m}$ de profundidade. Foi empregada uma solução nutritiva padrão, com a seguinte composição, em mmol/L: 16,9 de $\mathrm{NO}_{3}^{-} ; 2,0$ de $\mathrm{H}_{2} \mathrm{PO}_{4}^{-} ; 1,0$ de $\mathrm{SO}_{4}$ - 4,0 de $\mathrm{Ca}++; 10,9$ de $\mathrm{K}+\mathrm{e} \mathrm{1,0}$ de $\mathrm{Mg}++$, e, em mg L ${ }^{1}, 0,42$ de $\mathrm{Mn} ; 0,26$ de $\mathrm{Zn} ; 0,05$ de $\mathrm{Cu} ; 0,50$ de B; 0,04 de Mo, e 4,82 de Fe quelatizado. Os cinco níveis de salinidade foram obtidos por variações na concentração da solução nutritiva padrão, atingindo valores médios de condutividade elétrica (CE) de 0,$80 ; 1,93 ; 2,81 ; 3,73$ e 4,72 para T1, T2, T3, T4 e T5, respectivamente. A solução nutritiva em cada nível de salinidade foi fornecida a partir de um reservatório através de uma bomba submersa, durante $15 \mathrm{~min}$, em intervalos diurnos de $90 \mathrm{~min}$ e noturnos de $420 \mathrm{~min}$. Um dispositivo experimental inteiramente casualizado foi empregado, com quatro repetições e 20 plantas por parcela. Quatro plantas de cada tratamento foram coletadas aos 32 dias após o plantio para determinar a massa seca da parte aérea e das raízes, a massa fresca da parte aérea, a área foliar e o número de folhas. $\mathrm{O}$ número de folhas por planta foi igual a 18 , sem diferença significativa entre os tratamentos. A massa seca de folhas aumentou $24,4 \%$ de T1 para T3. A massa seca do caule foi reduzida nos níveis salinos mais elevados, porém não foi observada relação dos tratamentos com a massa seca do caule e das raízes. Foi observado efeito positivo na massa fresca da parte aérea, a qual aumentou $28,5 \%$ de T1 para T2, decrescendo $16,5 \%$ de T2 para T5. O valor máximo estimado do índice de área foliar foi de 4,3 $\mathrm{m}^{2} \mathrm{~m}^{-2}$ para uma EC de 2,6 $\mathrm{dS} \mathrm{m}{ }^{1}$. Concluiu-se que níveis salinos acima de 2,0 e 2,6 dS m ${ }^{1}$ reduzem o crescimento e a massa fresca das plantas, respectivamente.

Palavras-chave: Lactuca sativa, fertirrigação, hidroponia, salinidade.

(Recebido para publicação em 4 de novembro de 2004 e aceito em 5 de agosto de 2005)

$\mathrm{L}$ ettuce (Lactuca sativa) is the most important horticultural NFT-grown crop in Brazil. Standard nutrient solutions are prepared using high quality water and electrical conductivity is monitored daily to fit values between 1.4 and $2.0 \mathrm{dS} \mathrm{m}^{-1}$ (FAQUIN; FURLANI, 1999). This is so to prevent plant saline stress in periods of high transpiration demand, or reduction in growth rate due to low availability of mineral nutrients. The use of nutrient solutions prepared from low quality water or by re-using nutrient solutions has hardly been considered a possibility for this crop. The main reason is the high sensitivity of lettuce plants to salinity (SHANNON; GRIEVE, 1999). As a consequence, the remaining volumes of nutrient solution at the end of the cropping period are discharged in the environment. This practice is nowadays criticisable in a worldwide context searching for sustainable agricultural production systems.

One of the possibilities to reduce environmental pollution from hydroponical horticultural production systems is recycling and re-using the nutrient solution. The ionic concentration of the nutrient solutions used to grow horticultural crops is higher than that at which nutrients are absorbed by plants. Hence, the growth of the crop is followed by an increasing imbalance of the ionic concentration of the nutrient solution. In order to adjust periodically the ionic balance to the original level, it is necessary to do laboratory mineral analysis or electrodecomputing measurements. Both methods are difficult to carry out in the 
nowadays social and economic context of commercial production. For re-using a recycled nutrient solution without previous mineral nutrient analysis, a fraction of it is added to the standard nutrient solution being prepared, disregarding its mineral composition. This practice would lead to high salinity levels in the nutrient solution.

The initial effect of salinity at cellular level is due to its osmotic effects. Shoot and root growth rate is reduced, resulting in smaller and fewer leaves and shorter plant stature. The effects of salinity depends on interactions with environmental variables such as water vapour deficit, temperature and solar radiation (YEO,1999). Lettuce has been considered as a moderately salt sensitive crop, with a threshold electrical conductivity (EC) of $1.3 \mathrm{dS} \mathrm{m} \mathrm{m}^{-1}$, and a negative slope of 13.0 for each unit of added salinity above this threshold value (AYERS et al., 1951). Nevertheless, the root growing media may affect the response of plants to salinity. Pasternak et al. (1986) reported that yield and quality of soil grown lettuce was not affected by sprinkling with water at 4.4 $\mathrm{dS} \mathrm{m}{ }^{-1}$. Positive effects of salinity in fruit quality has been reported for horticultural soilless growing crops such as tomato (CUARTERO; MUÑOZ, 1999; LI; STANGUELLINI, 2001; BOLARIN et al., 2001) and muskmelon (MAVROGIANOPOULOS et al., 1999). For hidroponically grown lettuce crops, results are scarce in the literature.

The goal of this work was to determine the effect of salinity on growth, development and yield of hydroponically grown lettuce plants.

\section{MATERIAL AND METHODS}

An experimental set-up was made inside a polyethylene tunnel, at the Universidade Federal de Santa Maria. The soil surface was dug up in order to make a $1.3 \mathrm{~m}$ length, $1.2 \mathrm{~m}$ width and $0.25 \mathrm{~m}$ depth tank into the soil, which was covered with a $200 \mathrm{~m} \mu$ black polyethylene sheet. A fibber cement tile (3.05 m length and $1.10 \mathrm{~m}$ width) was placed over the tank with a slope of $3 \%$ and covered with a $200 \mathrm{~m} \mu$ black polyethylene sheet. The tile gullies were filled with $0.015-0.025 \mathrm{~m}$ particle size gravel and covered with a $1,5 \times 10^{-3} \mathrm{~m}$ polyethylene screen. Sand of 0.0015$0.003 \mathrm{~m}$ particle size was used to make up a $0.15 \mathrm{~m}$ depth growing bed over the tile. (For more details, see ANDRIOLO et al., 2004). A flooded-type electrical pump was placed at the bottom of the upper end of the tank, and connected to a pipe to drive the nutrient solution up to the surface of the sand bed. The pump was put to work by means of a timer until the nutrient solution started to flow away from the lower side of the growing bed. After the pump was switched off, the nutrient solution drained off from the growing bed across the polyethylene screen and the tile gullies. Finally, the set-up was covered by a white polyethylene sheet.

On June 18, 2004, six-leaved lettuce plantlets, cv. Vera, were transferred to the sand bed through cuttings made in the polyethylene sheet. Plant density was 25 plants $\mathrm{m}^{-2}$. Water and nutrients were supplied by means of a standard nutrient solution with the following composition, in mmol $\mathrm{L}^{-1}$ (CASTELLANE; ARAÚJO, 1995): $16.9 \mathrm{NO}_{3}^{-} ; 2.0 \mathrm{H}_{2} \mathrm{PO}_{4}^{-} ; 1.0 \mathrm{SO}_{4}-; 4.0$ $\mathrm{Ca}++; 10.9 \mathrm{~K}+$ and $1.0 \mathrm{Mg}++$, and, in $\mathrm{mg} \mathrm{L}^{-1}, 0.42 \mathrm{Mn} ; 0.26 \mathrm{Zn}$; 0.05 Cu; 0.50 $\mathrm{B} ; 0.04 \mathrm{Mo}$, and 4.82 chelate $\mathrm{Fe}$. The $\mathrm{pH}$ and electrical conductivity (EC) was 5.8 and $2.9 \mathrm{dS} \mathrm{m}^{-1}$, respectively. The pump delivered the nutrient solution for 15 minutes, at intervals of 90 minutes during the day and 420 minutes during the night. The tunnel was ventilated on sunny days by opening the lateral sides, to reach similar values of maximum air temperatures inside and outside of it.

Five salinity levels were compared as treatments, obtained by varying the concentration of the standard nutrient solution. The target EC values of treatments were $0.8 ; 1.85 ; 3.0 ; 4.0$ and $5.0 \mathrm{dS} \mathrm{m}{ }^{-1}$, for T1, T2, T3, T4 and T5, respectively. The actual EC values averaged over the experimental period were $0.80 ; 1.93 ; 2.81 ; 3.73$ and $4.72 \mathrm{dS}$ $\mathrm{m}^{-1}$, respectively. Electrical conductivity and $\mathrm{pH}$ were measured daily. A volume of water or an aliquot of nutrient solution at the required concentration was added every time the measured EC value was
$10 \%$ above or below the original value, respectively. The volumes to be added were estimated by a proportionality coefficient of the volume of nutrient solution contained into the reservoir, estimated by the depth of the liquid inside it. The $\mathrm{pH}$ was maintained in the range between 5.0 e 6.0 by additions of $\mathrm{H}_{3} \mathrm{PO}_{4}$ or $\mathrm{KOH}$, from a titration curve previously determined in the laboratory. A completely randomised experimental design was used, with four replications and an experimental set-up for each plot.

Four plants of each plot were harvested at 32 days after planting (DAP), when fully expanded older leaves began to senesce. The number of leaves longer than $0.01 \mathrm{~m}$ were counted. Specific leaf area (SLA) was determined on the basis of dry mass of 100 leaf disks $\left(5^{\prime} 10^{-4} \mathrm{~m}^{2}\right)$, sampled on all leaves. Leaf area index (LAI) was estimated by extrapolating the SLA to the plant leaf dry mass. Shoot fresh weight was determined and roots were carefully removed out from the sand and washed in water. Dry mass of leaves, stem and roots were determined after drying at $60^{\circ} \mathrm{C}$ until constant dry weight was reached. Statistical models were fitted by regression analysis.

\section{RESULTS AND DISCUSSION}

The number of leaves was 18 per plant and was not affected by treatments. Dry mass of leaves increased $24,4 \%$ from T1 to T3 (Figure 1a). Treatments T4 and T5 maintained this value and the data fitted a polynomial model (Figure 1a). Stem dry mass was slightly reduced, root dry mass was not affected by treatments, and no relationship was found on data from both variables (Figure 1a). Dry mass fractions did not differ among treatments, and average values were 0.93 for leaves, 0.02 for stem and 0.05 for roots.

A positive effect of EC levels was recorded on shoot fresh mass, which increased $28.5 \%$ from $\mathrm{T} 1$ to $\mathrm{T} 2$, fitting a polynomial model with a maximum estimated value of $170.7 \mathrm{~g} /$ plant for an EC of $2.0 \mathrm{dS} \mathrm{m} \mathrm{m}^{-1}$ (Figure 1b). A 16.5\% linear decrease was found from $\mathrm{T} 2$ to T5. Leaf area data fitted a polynomial model, with a maximum LAI estimated 
value of $4.3 \mathrm{~m}^{2} / \mathrm{m}^{2}$ for an $\mathrm{EC}$ of $2.6 \mathrm{dS}$ $\mathrm{m}^{-1}$ (Figure 2).

Lettuce growth was affected by low concentrations of the nutrient solution, probably due to low availability of mineral nutrients. Nevertheless, dry mass accumulation was not reduced at concentrations of the nutrient solution higher than $2.8 \mathrm{dS} \mathrm{m}^{-1}$. This implies uptake of carbon by leaves and mineral nutrients by roots were not affected. Effects of salinity on plant growth and yield have been attributed to simultaneous reduction in leaf area and root growth, affecting photosynthesis and water and mineral uptake (SHANON; GRIEVE, 1999). Salinity has been measured as the total salt concentration in the root media, disregarding ions in solution. Nevertheless, when salinity is due to $\mathrm{NaCl}$, its effects are associated with accumulation of $\mathrm{Na}^{+}$and $\mathrm{Cl}^{-}$in cells and/ or to ionic imbalance leading to physiological disturbances (BOLARIN et al., 2001). This was not the case in the present experiment, as a balanced nutrient solution was prepared from high quality water. When dealing with salinity, it should be advisable to separate the effects from water with $\mathrm{NaCl}$ from those arising from the concentration of the nutrient solution. This conclusion should be considered while growing fruiting horticultural crops commercially at high EC levels to improve physiological quality (CUARTERO; FERNADEZ-MUÑOZ, 1999; LI; STANGUELLINI, 2001).

Although plant dry mass was not affected by high nutrient solution concentrations, fresh weight and leaf area were reduced. This effect might be attributed to its influence on water uptake by plants. The estimated upper threshold value of $2.0 \mathrm{dS} \mathrm{m} \mathrm{m}^{-1}$ and the linear slope of -14.9 (Figure 1b) were higher than those of $1.3 \mathrm{dS} \mathrm{m}^{-1}$ and 13.0 respectively, reported by Ayers et al. (1951). These discrepancies might be associated to genotype differences and to environmental conditions influencing plant water demand. The effect on fresh weight was more pronounced than on leaf area, suggesting leaves had some degree of plasticity at low water deficit. Nevertheless, when water deficit rises
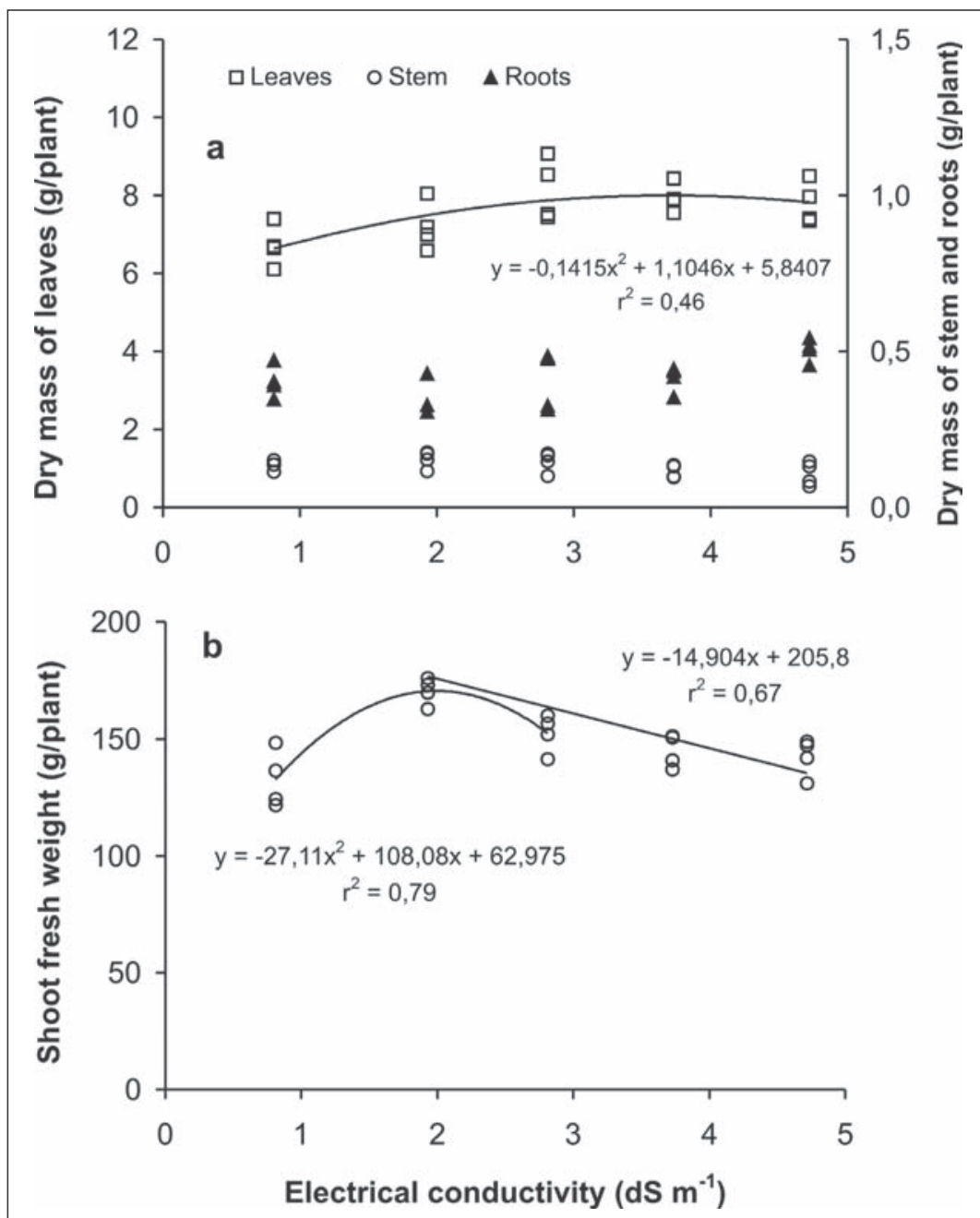

Figure 1. Dry mass of shoot organs (a) and shoot fresh weight (b) of lettuce plants grown hydroponically at five concentrations of the nutrient solution. Santa Maria, UFSM, 2004.

by effect of high nutrient solution concentration, its influence on leaf area was similar to that on fresh weight.

Present results were obtained in winter, when daily maximum air temperatures did not exceed $29^{\circ} \mathrm{C}$ and average global solar radiation was about 8.4 $\mathrm{MJ} \mathrm{m}^{-2}$ day $^{-1}$ (BURIOL et al., 2000). This environmental condition was near the optimal $15-25^{\circ} \mathrm{C}$ range for the lettuce crop (GOTO, 1998). Thus, relationships showed in this paper could be interpreted as a preponderant effect of the nutrient solution concentration. These effects might be enhanced by environmental conditions stimulating water uptake by plants (YEO, 1999), such as high temperatures and solar radiation during spring and summer. In this way, a second variable estimating the effect of environment on growth under saline conditions should be determined and considered when dealing with mechanistical models for the lettuce crop. The time intervals of fertigation should also be considered. Short time intervals between fertigations might be used to prevent the rising in salinity in the rooting media as a consequence of plant transpiration. In this case, growing in sand or other substrates would be similar to doing it in NFT facilities. On the other hand, if long time intervals between fertigations are used, EC values may increase, reducing plant fresh weight and leaf area.

Marketable quality of lettuce is determined mainly by plant size, which depends on fresh weight. For 


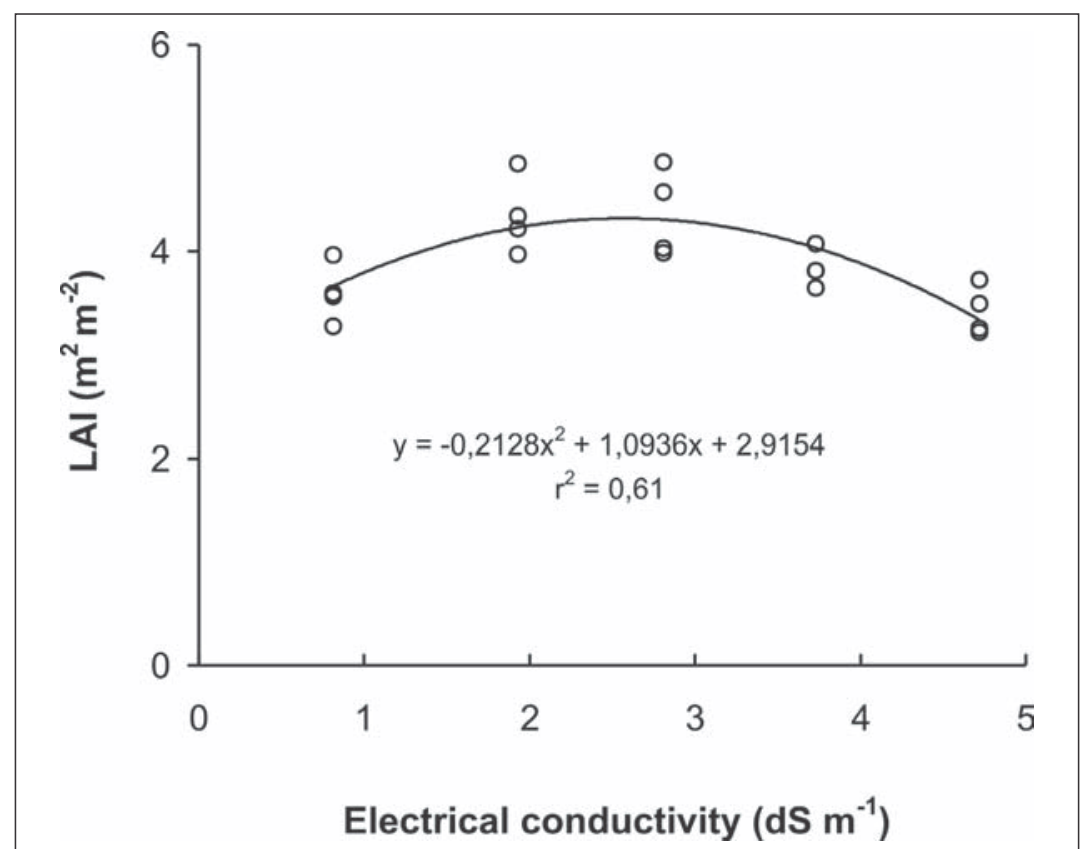

Figure 2. Leaf area index (LAI) of lettuce plants grown hydroponically at five concentrations of the nutrient solution. Santa Maria, UFSM, 2004.

commercial purposes, results showed that salinity levels above 2.0 and $2.6 \mathrm{dS}$ $\mathrm{m}^{-1}$ reduce fresh yield and plant growth, respectively. On the other hand, the fact that, plants were able to grow shoot and roots with a nutrient solution conductivity of about $4.7 \mathrm{dS} \mathrm{m}^{-1}$ suggests that water uptake is the key variable controlling lettuce plant size at concentrations of the nutrient solution above the threshold value. In this way, recycling and re-using nutrient solutions is a practice that could be taken in account. This might be done by adding successive aliquots of recycled nutrient solutions during the growth of the crop, every time the measured EC values of the nutrient solution had to be raised to its original threshold. This hypothesis should be tested by more experiments.

\section{CITED LITERATURE}

ANDRIOLO, J.L.; LUZ, G.L.; GIRALDI, C.; GODOI, R.S.; BARROS, G.T. Cultivo hidropônico da alface empregando substratos: uma alternativa a NFT?. Horticultura Brasileira, Brasília, v.22, n.4, p.794-798, 2004.
AYERS, A.D.; WADLEIGH, C.H.; BERNSTEIN, L. Salt tolerance of six varieties of lettuce. Proceedings of the American Society for Horticultural Science, v.57, p.237-242, 1951.

BOLARIN, M.C.; ESTAN, M.T.; CARO, M.; ROMERO-ARANDA, R.; CUARTERO, J.

Relationship between tomato fruit growth and fruit osmotic potential under salinity. Plant Science, v.160, p.1153-1159, 2001.

BURIOL. G.A.; ESTEFANEL, V.; ANDRIOLO, J.L.; MATZENAUER, R.; TAZZO, I.F. Disponibilidade de radiação solar para o cultivo do tomateiro durante o inverno no Estado do Rio Grande do Sul. Pesquisa Agropecuária Gaúcha, v.6, n.1, p.113-120, 2000.

CASTELlANE, P.D.; ARAÚJO, J.A.C. Cultivo sem solo - Hidroponia. 4. ed. Jaboticabal: FUNEP, 1995. $43 \mathrm{p}$

CUARTERO, J.; FERNÁNDEZ-MUÑOZ, R.

Tomato and salinity. Scientia Horticulturae, v.78, p.83-125, 1999

FAQUIN, V.; FURLANI, P.R. Cultivo de hortaliças de folhas em hidroponia em ambiente protegido. Informe Agropecuário, v.20, n.200/201, p.99-104, 1999.

GOTO, R. A cultura da alface. In: GOTO, R.; TIVELLI, S.W. (Ed.). Produção de hortaliças em ambiente protegido: condições subtropicais. São Paulo: FUNESP, 1998, p.137-159.

LI, Y.L.; STANGHELLINI, C. Analysis of the effect of EC and potential transpiration on vegetative growth of tomato. Scientia Horticulturae, v.89, p.9-21, 2001.

MAVROGIANOPOULOS, G.N.; SPANAKIS, J.; TSIKALAS, P. Effect of carbon dioxide enrichment and salinity on photosynthesis and yield in melon. Scientia Horticulturae, v.79, p.51-63, 1999.

PASTERNAK, D., DE MALACH, Y., BOROVIC, I., SHRAM, M., AVIRAM, C. Irrigation with brackish water under desert conditions. IV. Salt tolerance studies with lettuce (Lactuca sativa L.). Agric. Water Manage, v.11, p.303-311. 1986. SHANNON, M.C.; GRIEVE, C.M. Tolerance of vegetable crops to salinity. Scientia Horticulturae, v.78, p.5-38, 1999

YEO, A. Predicting the interaction between the effects of salinity and climate change on crop plants. Scientia Horticulturae, v.78, p.159-174, 1999. 